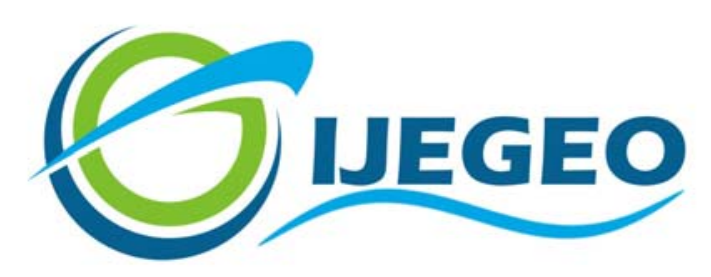

International Journal of Environment and Geoinformatics (IJEGEO) is an international, multidisciplinary, peer reviewed, open access journal.

\title{
Impacts and Mitigation Approach of Flue Gas (SO2) in Coal Fired Power Plant of Bangladesh
}

\author{
H.M. Rayhan RIFAT, Zayed Bin SULTAN
}

\author{
Chief in Editor \\ Prof. Dr. Cem Gazioğlu \\ Co-Editors \\ Prof. Dr. Dursun Zafer Şeker, Prof. Dr. Şinasi Kaya, \\ Prof. Dr. Ayşegül Tanık and Assist. Prof. Dr. Volkan Demir
}

\section{Editorial Committee (December 2020)}

\begin{abstract}
Assos. Prof. Dr. Abdullah Aksu (TR), Assit. Prof. Dr. Uğur Algancı (TR), Prof. Dr. Bedri Alpar (TR), Prof. Dr. Levent Bat (TR), Prof. Dr. Paul Bates (UK), İrşad Bayırhan (TR), Prof. Dr. Bülent Bayram (TR), Prof. Dr. Luis M. Botana (ES), Prof. Dr. Nuray Çağlar (TR), Prof. Dr. Sukanta Dash (IN), Dr. Soofia T. Elias (UK), Prof. Dr. A. Evren Erginal (TR), Assoc. Prof. Dr. Cüneyt Erenoğlu (TR), Dr. Dieter Fritsch (DE), Prof. Dr. Çiğdem Göksel (TR), Prof.Dr. Lena Halounova (CZ), Prof. Dr. Manik Kalubarme (IN), Dr. Hakan Kaya (TR), Assist. Prof. Dr. Serkan Kükrer (TR), Assoc. Prof. Dr. Maged Marghany (MY), Prof. Dr. Michael Meadows (ZA), Prof. Dr. Nebiye Musaoğlu (TR), Prof. Dr. Masafumi Nakagawa (JP), Prof. Dr. Hasan Özdemir (TR), Prof. Dr. Chryssy Potsiou (GR), Prof. Dr. Erol Sarı (TR), Prof. Dr. Maria Paradiso (IT), Prof. Dr. Petros Patias (GR), Prof. Dr. Elif Sertel (TR), Prof. Dr. Nüket Sivri (TR), Prof. Dr. Füsun Balık Şanlı (TR), Prof. Dr. Uğur Şanlı (TR), Duygu Ülker (TR), Prof. Dr. Seyfettin Taş (TR), Assoc. Prof. Dr. Ömer Suat Taşkın (US), Assist. Prof. Dr. Tuba Ünsal (US), Dr. İnese Varna (LV), Dr. Petra Visser (NL), Prof. Dr. Selma Ünlü (TR), Prof. Dr. Murat Yakar (TR), Assit. Prof. Dr. Sibel Zeki (TR)
\end{abstract}

Abstracting and Indexing: TR DIZIN, DOAJ, Index Copernicus, OAJI, Scientific Indexing Services, International Scientific Indexing, Journal Factor, Google Scholar, Ulrich's Periodicals Directory, WorldCat, DRJI, ResearchBib, SOBIAD 


\title{
Review Article
}

\section{Impacts and Mitigation Approach of Flue Gas (SO2) in Coal Fired Power Plant of Bangladesh}

\author{
H M Rayhan Rifat*, ${ }^{2}$ Tayed Bin Sultan \\ Chittagong University of Engineering and Technology, Mechanical Faculty, Department of Petroleum and Mining Engineering (PME), Chittagong - \\ Bangladesh.
}

E-mail: rayhanrifat1@gmail.com

Received 15 Fenb 2020 Accepted 23 Sept. 2020

How to cite: Rifat and Sultan (2020). Impacts and Mitigation Approach of Flue Gas (SO2) in Coal Fired Power Plant of Bangladesh, International Journal of Environment and Geoinformatics (IJEGEO), 7(3): 319-324. DOI: 10.30897/ijegeo.734144

\begin{abstract}
Energy demand of Bangladesh is rising continuously. Therefore, several power plants have been establishing, where the main fuel is a coal to satisfy this requirement. In Barapukuria, a coal-based power plant has already been activated to produce $250 \mathrm{MW}$ electricity. The coal-fired power plant in Matarbari (1200 MW), Payra Thermal Power Plant (1320 MW), Rampal Power Plant $(1320 \mathrm{MW})$ are under construction in addition to add $3840 \mathrm{MW}$. While boasting our power grid, it raises the concern of environmental adversity that may occur by the emission of flue gases ( $\mathrm{SO} 2, \mathrm{NOx}, \mathrm{CO} 2)$ and particulate material from the chimney. This exhaust emission causes a discrepancy in human health and the environment. Among these flue gases SO2 is prime concern here. Hence, this study is done to identify the adversity of this pollutant. For this reason, the amount of flue gas (SO2) is calculated which will help to understand the deviation from standard values. If any deviation is identified, mitigation steps should be taken to prevent the adversity. There are various methods to mitigate the flue gas (SO2), for example, wet scrubber, limestone/gypsum system, ammonia scrubbing, lime/limestone scrubbing for mitigation of sulfur dioxide (SO2). According to the suitability and efficiency of these processes, the best methods are explained to capture the flue gas (SO2) for saving our environment.
\end{abstract}

Keywords: Energy demand of Bangladesh, SO2, CPPs, Impacts, Mitigation.

\section{Introduction}

Electricity is the key source of power for most aspects of the economy in the world. Bangladesh's overall installed electricity generation capacity (including captive power) was $15,351 \mathrm{MW}$ as of January 2017 (Wikipedia, 2020) and 20,000 MW in 2018 (Dhakatribune, 2019). The main energy users in Bangladesh are the factories and the housing sector, followed by the commercial and horticultural sectors. Bangladesh has seen a robust economic growth of approximately 6.5 percent (Rahman et al, 2012). By 2030, Bangladesh will need an additional 34,000 MW of exactly to support its economic growth of more than $7 \%$ (Sieed et al., 2015). So, several power plants are planned to establish where coal-fired plants are favorable due to high efficiency and low cost.

In Bangladesh, at Barapukuria in January 2006, the first coal-fired power station tarted commercially manufacturing at $250 \mathrm{MW}$. This coalfired power plant operates under subcritical vapor.

Another 2000MW coal-based power is also signed. Payra Thermal Power Plant 1320 (MW), Rampal Power Plant 1320 (MW) The Matarbari 1200MW power station, Banshkhali power station 1,224 (MW) are ongoing projects. Therefore, these power plants will help us to enhance our capability and boost our energy sector (www.cpgcbl.gov.bd, 2019).

Along this, it raises the concern of environmental impacts of our country. As the primary constituents of coal are formed by soil, volatile matter, carbon, sulfur and so on, coal-fired electricity generation creates unsustainable pollution. In one year, coal-based power stations burn enormous amounts of coal, emitting enormous volumes of sulfide oxide (SO2). However, among the other sources, the largest source of $\mathrm{SO} 2$ is known as the fossil fuel combustion (Bayırhan, et al., 2019; Ülker et al., 2018; Zhang et al., 2017) national energy policy also gives priority to the use of mainly domestic fossil resources for energy production in the future. As a prime trace gas, SO2 plays a substantial role in the troposphere in atmospheric complex processes such as haze and photochemical smog (Mersin et al., 2019; Tokuşlu 2020). Additionally, SO2 causes acid rain when water is present in the atmosphere. Acid rain destroys forests and ecology, disrupts the acidic balance of the aquatic environment, and causes corrosion on building materials (Arslan and Akyürek, 2018; Fioletov, et al., 2013). Studies showed that $\mathrm{SO} 2$ is associated with cardiovascular abnormalities irritates the respiratory system affects lung functions, causes eye irritation, and increases susceptibility to respiratory infections by weakening the immune system (Lin et al., 2018). Yet, the consequences can be plunged 
utilizing various control measures and recovered SO2 from flue gas can be used to produce.

\section{Methodolog \\ Study area}

Until now, there is only one coal fired power plant is operating and the rest of them are in under construction. The figure 1 represents location of the plants. At Phulbari Upazila of Dinajpur District, Barapukhuria power station is established in the northern part of the Bangladesh whereas other three will be established in the southern part of the country. Matarbari Power station, Payra Thermal Power Plant, Rampal Power Plant are developed in Maheshkhali Upazila of Cox's
Bazar District, Sapmari, Rampal Upazila of Bagerhat District, Kalapara Upazila of Patuakhali District respectably. Having population over 0.1 million within 229.5 square km, Phulbari Upazila consisting population density 1781 per square $\mathrm{km}$, where literacy rate is only about 32.48. Moreover, a lack of health consciousness is prevailing there at a great instance. On the other hand, Rampal Upazila has occupied 335.46 square $\mathrm{km}$ with population over 0.1 million. Besides, Rampal Upazila is close to largest mangrove frorest called Sundarban. Kalapara Upazila and Maheshkhali Upazila are occupying $483.1 \mathrm{~km}^{2}$ and $362.2 \mathrm{~km}^{2}$ respectably (Islam et al., 2016, Rashidin et al., 2019).

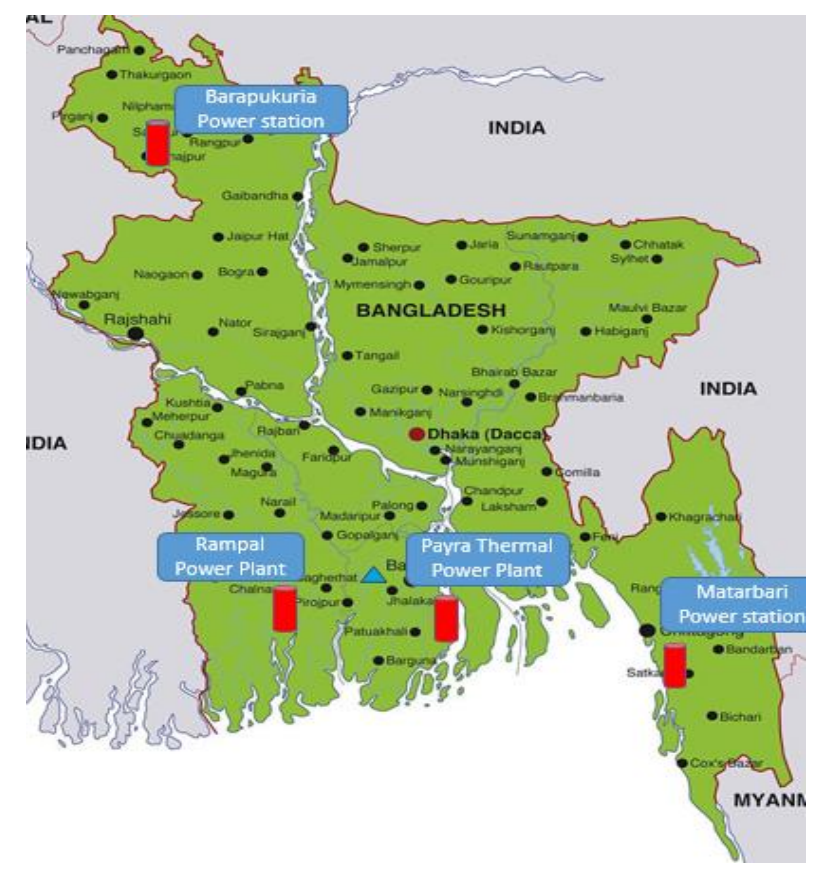

Figure 1. Position of coal fired power plant of Bangladesh.

\section{Emission estimation}

The amount of SO2 emits is calculated by mass balance equation

$\mathrm{Sin}=\mathrm{Sash}+\mathrm{SSO} 2$

Sin $=$ amount of coal $\times$ percentage of sulfur

Sash $=\operatorname{Sin} \times$ percentage of ash

The amount of Sulfur available for conversion to SO2

$\mathrm{SaSO} 2=\mathrm{Sin}-\mathrm{Sash}$

The amount of Sulfur dioxide formed is then $\frac{64}{32}$ of the sulfur available for conversion.

$\mathrm{SSO} 2=\frac{64}{32} \times \mathrm{SaSO} 2$

The amount of Sulfur dioxide formed in the flue gas in unit $\mathrm{kg} / \mathrm{h}$ calculated by
$\mathrm{SO} 2(\mathrm{~kg} / \mathrm{h})=$ amount of coal $\times$ percentage of sulfur $\left(1-\right.$ percentage of ash) $\times 2 \times \frac{907.15}{365 \times 24}$

A table is shown, where coal properties such as ash content and sulfur content are provided and coal will be used from the tabulated country.

\section{Results and Discussion Emission of SO2}

The main source of the SO2 emission is coal since sulfur is one of the constituents of it. The coal, which is found in Bangladesh having sulfur approximately 0.53 percent. On the contrary Bangladesh is going to import coal from Australia, South Africa and Indonesia where sulfur percentage higher than the domestic one. Table 1 reveals the properties of the imported coal. The present scenario of coal-fired power plants is shown in table 2 where operating technologies, coal types, Planned/ operating power (MW), State, Coal Use ton per year are mentioned. The amounts of sulfur dioxide will be produced by using coal imported from different countries in four coal-fired power plants are mentioned in table 3 . 
Table 1. Coal properties (Safiullah, et al., 20111).

\begin{tabular}{lll}
\hline Countries for coal & Ash content (approximate) & Sulfur content (approximate) \\
\hline Bangladesh & $12.4 \%$ & $0.53 \%$ \\
Australia & $13.60 \%$ & $0.63 \%$ \\
South Africa & $14.2 \%$ & $0.6 \%$ \\
Indonesia & $13.18 \%$ & $2.32 \%$ \\
\hline
\end{tabular}

Table 2. Information on operating and proposed CPPs in Bangladesh

\begin{tabular}{|c|c|c|c|c|c|}
\hline CPPs & Technology & Coal type & $\begin{array}{c}\text { Planned/ } \\
\text { operating } \\
\text { power }(\mathrm{MW})\end{array}$ & State & $\begin{array}{c}\text { Coal } \\
\text { use ton } \\
\text { per year }\end{array}$ \\
\hline $\begin{array}{l}\text { Barapukuria } \\
\text { Power station }\end{array}$ & -- & $\begin{array}{c}\text { Domestic } \\
\text { (Anthracite) }\end{array}$ & 525 & Operating & 481800 \\
\hline $\begin{array}{c}\text { Matarbari Power } \\
\text { station }\end{array}$ & $\begin{array}{l}\text { Ultra-super } \\
\text { critical }\end{array}$ & $\begin{array}{l}\text { Imported (Sub- } \\
\text { bituminous) }\end{array}$ & 1200 & Proposed & 3730000 \\
\hline $\begin{array}{c}\text { Payra Thermal } \\
\text { Power Plant }\end{array}$ & $\begin{array}{l}\text { Ultra-super } \\
\text { critical }\end{array}$ & $\begin{array}{l}\text { Imported (Sub- } \\
\text { bituminous) }\end{array}$ & 1320 & Proposed & 4120000 \\
\hline $\begin{array}{l}\text { Rampal Power } \\
\text { Plant }\end{array}$ & $\begin{array}{l}\text { Ultra-super } \\
\text { critical }\end{array}$ & $\begin{array}{l}\text { Imported (Sub- } \\
\text { bituminous) }\end{array}$ & 1320 & Proposed & 4720000 \\
\hline
\end{tabular}

Table 3. SO2 $(\mathrm{kg} / \mathrm{h})$ produce by coal combustion

\begin{tabular}{ccccc}
\hline CPPs & \multicolumn{3}{c}{ SO2 $(\mathrm{kg} / \mathrm{h})$ produce by using coal from different countries } \\
& Bangladesh & Australia & South Africa & Indonesia \\
\hline $\begin{array}{c}\text { Barapukuria } \\
\text { Power station }\end{array}$ & 463.2 & 543.1 & 513.7 & 2009.9 \\
$\begin{array}{c}\text { Matarbari Power station } \\
\text { Payra Thermal Power }\end{array}$ & 3586.6 & 4205 & 3976 & 15560.4 \\
Plant & 3961.7 & 4644.6 & 4392.7 & 17187.3 \\
Rampal Power Plant & 4538.6 & 5321 & 5032.5 & 19690.4 \\
\hline
\end{tabular}

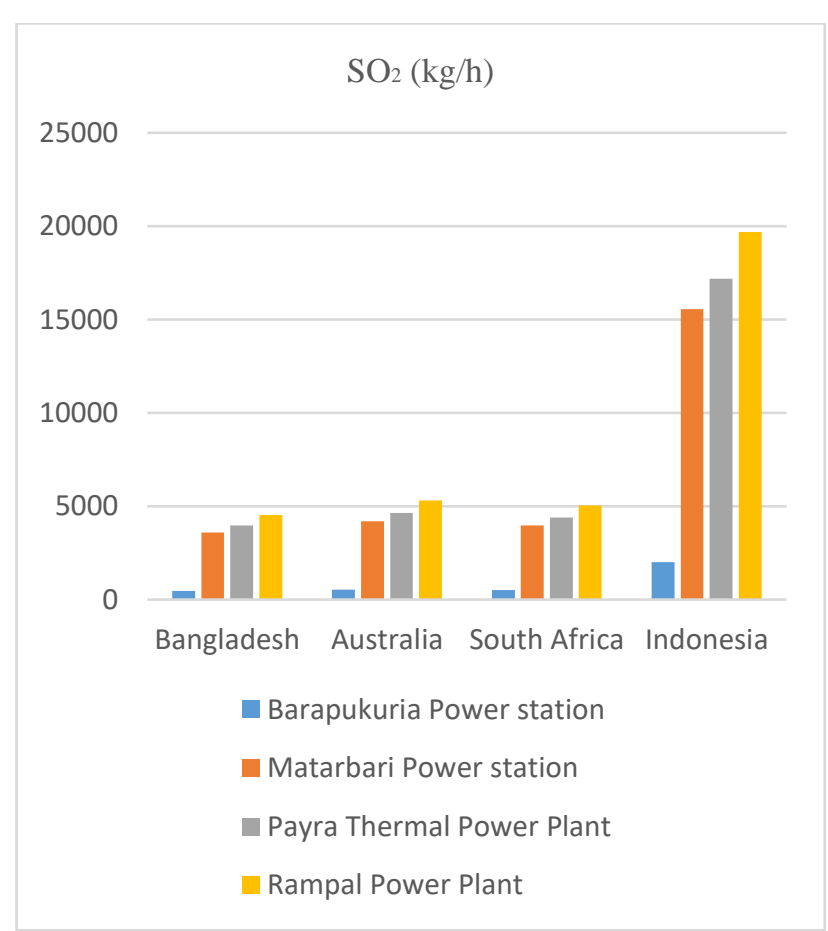

Figure 2. A comparison of SO2 emission by using coal of different countries. 


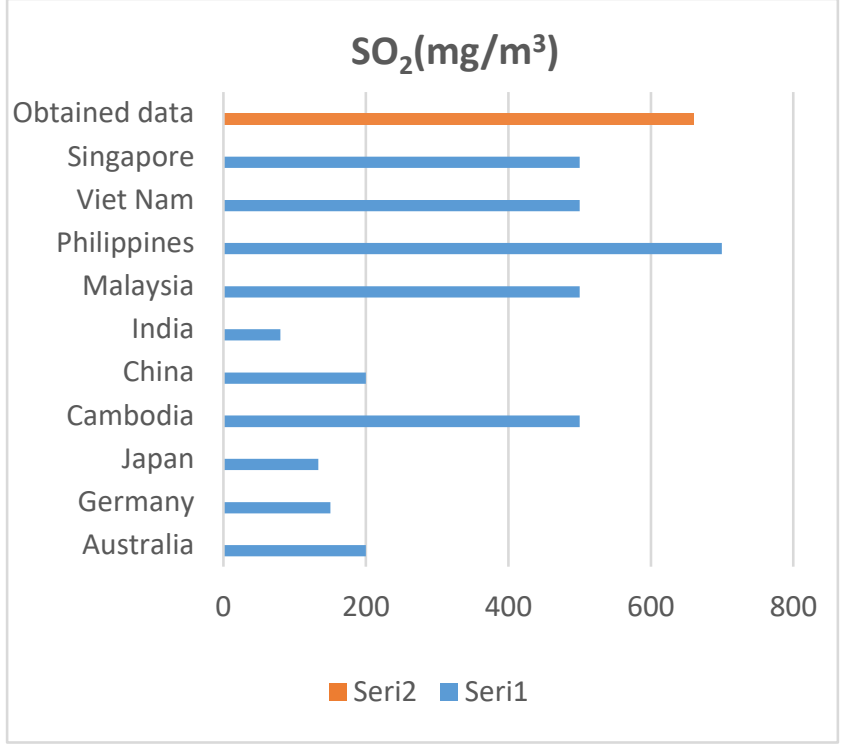

Figure 3. Comparison of SO2 emission.

Deviation Determination: Here, obtained data represents the SO2 concentration that is produced from Barapukuria Power station, depicting considerably higher rate than other countries.

Deviation impact: Here, measured values show that the deviation is not too much. Though the values are small in quantity, it has significant impact on human being and environment.

Deviation impact on human: Sulfur dioxide amuses the ears, mouth, neck, and organs (lungs) skin and sinuses membranes. High SO2 levels, particularly during intense physical activity, can trigger infection and discomfort of the respiratory tract. The ensuing signs may include pain in deep breathing, coughing, inflammation of the neck, and difficulty breathing. High levels of SO2 in delicate communities may influence lung function, worsen migraines, and worsen current heart disease. This fume can also respond with other airborne chemicals and turn into a tiny particle that would enter the lungs and trigger comparable impacts on wellness. The minimum level of pulmonary structure alterations in asthma exercise is of the range of $1144 \mu \mathrm{g} / \mathrm{m}^{3}$, although tiny shifts in airway resistance of $286 \mu \mathrm{g} / \mathrm{m}^{3}$ in two sensitive objects (Craig, et al., 2008). The concentration of SO2 in the area of Barapukuria around 4 kilometer is $0.2300 \mathrm{mg} / \mathrm{m}^{3}$ (maximum concentration), where Bangladesh permit 2 $\mathrm{mg} / \mathrm{m}^{3}$ (Alam, 2013).

Deviation impact on environment: The gas SO2, that is emitted contribute to acid rain. Acid rain is described as any type of moist precipitation that has a $\mathrm{pH}$ of less than 5.6 in mist, dew, snow, hail or rain. Pure water has a $\mathrm{pH}$ of 7.0 (balanced), but conventional, unpopulated rainwater has a $\mathrm{pH}$ of approximately 5.6 (aromatic). Rainwater is mildly acidic, of course. The acidity of rainwater is due to the normal existence in the reduced atmosphere of three components $\left(\mathrm{CO}_{2}\right.$ coal carbonate, NO nitric oxide and SO2 sulfur dioxide) (Prinn and Fegley, 1987). The following reactions describe how this contribute,

$$
\begin{gathered}
\mathrm{SO} 2(\mathrm{~g})+\mathrm{O}_{2}(\mathrm{~g}) \rightarrow \mathrm{SO}_{3}(\mathrm{~g}) \\
\mathrm{SO}_{3}(\mathrm{~g})+\mathrm{H}_{2} \mathrm{O}(\mathrm{l}) \rightarrow \mathrm{H}_{2} \mathrm{SO}_{4}(\mathrm{aq})
\end{gathered}
$$

Sulfuric acid is a powerful acid, so it dissociates easily in water, giving an $\mathrm{H}+$ proton and an $\mathrm{HSO}_{4}{ }^{-}$element. To deliver $\mathrm{H}^{+}$and $\mathrm{SO}_{4}{ }^{2-}$, the $\mathrm{HSO} 4$ ion can further separate. Thus, the existence of $\mathrm{H}_{2} \mathrm{SO}_{4}$ drastically increases the amount of $\mathrm{H}_{+}$electrons, so the rainwater $\mathrm{p}^{\mathrm{H}}$ falls to dangerous concentrations.

$$
\begin{aligned}
& \mathrm{H}_{2} \mathrm{SO}_{4}(\mathrm{aq}) \rightarrow \mathrm{H}^{+}(\mathrm{aq})+\mathrm{HSO}_{4}^{-}(\mathrm{aq}) \\
& \mathrm{HSO}_{4}^{-}(\mathrm{aq}) \rightarrow \mathrm{H}^{+}(\mathrm{aq})+\mathrm{SO}^{2-}(\mathrm{aq}
\end{aligned}
$$

\section{Mitigation Approach}

The coal used by Barapukhuria has less sulfur percentage as well as consume less amount of coal per year compare to other three power plants that are under construction. Moreover, to meet the demand coal are to be imported from abroad having higher percentage of sulfur which means higher amount of $\mathrm{SO} 2$ will be produced soon. Therefore, mitigation approach should be applied to protect our inhabitants and us.

\section{Mitigation Approach for SO2}

Different techniques for SO2 monitoring are focused on either SO2 pollution reduction or the end of pipe extraction process for flue gas. The simplest one is use coal, which has less amount of sulfur or mix with coal containing less amount of sulfur. Because SO2 emission is proportional to amount of sulfur content of coal. To reduce sulfur coal can be washed before putting in to fire. Washing coal act as desulfurizing treatment. Despite this simple process, $\mathrm{SO} 2$ can be removed from exhaust gas by using FGD system. Flue gas desulfurization (FGD) process has various classification. These are wet scrubber, limestone/gypsum system, ammonia scrubbing, lime/limestone scrubbing etc. Other than FGD system, Dry and semi-dry scrubbing, Wet regenerative processes are also applicable to prevent $\mathrm{SO} 2$ emission. 
Table 4 Overall comparisons of SO2 control systems

\begin{tabular}{lcc}
\hline System & Percent SO2 reduction & Capital cost $(\$ / \mathrm{kw})$ \\
\hline Sorbent injection & $30-70$ & $50-100$ \\
Dry flue gas desulphurization & $70-90$ & $80-170$ \\
Wet flue gas desulphurization & $>90$ & $80-150$ \\
\hline
\end{tabular}

Considering all the treatment procedure for Barapukuria power plant lime/limestone scrubbing washing the coal properly. Bangladesh has a biggest deposit of limestone in Naogaon. It will be a cost-efficient choice. Moreover, this process is the most popular method. Usually the vertically focused spray tower use counter current for the absorbent application. When the $\mathrm{CaSO}_{4}$ percentage exceeds 15 , the gypsum scale is created. The method of lime stone forced oxidation (LSFO) avoids the development of this scale by pushing oxidation of $\mathrm{CaSO}_{3}$ to $\mathrm{CaSO}_{4}$ by pumping air into the conversion tank or an extra reserve tank. More than $90 \%$ of the U.S. flue gas desulfurization system capacity in the United States utilizes lime or calcareous. This trend is probable to proceed into the next stage of federally mandated decrease of SO2 from coal-fired power stations. This is about $80 \%$ of the market share and is used in big utility boilers. This is due to the high effectiveness of removal of SO2 and low expenses (Roy and Sardar, 2015). Wet FGD treatment can also apply for our future power plants that will have $700 \mathrm{MW}$ or $1200 \mathrm{MW}$. These will consume more coal and coal will be imported so sulfur percent will not same as Barapukuria coal field. This treatment has removal efficiency from 97 to $99.3 \%$ (Initiative, 20003). The process includes the following reactions.

$\mathrm{S}(\mathrm{Coal})+\mathrm{O}_{2}---->\mathrm{SO}_{2}$
$\mathrm{SO} 2+1 / 2 \mathrm{O}_{2}---->\mathrm{SO}_{3}$
$\mathrm{Absorption}$
$\mathrm{SO} 2+\mathrm{H}_{2} \mathrm{O}---->\mathrm{H}_{2} \mathrm{SO}_{3}$
$\mathrm{SO}_{3}+\mathrm{H}_{2} \mathrm{O}---->\mathrm{H}_{2} \mathrm{SO}_{4}$

Neutralization

$\mathrm{CaCO}_{3}+\mathrm{H}_{2} \mathrm{SO}_{3}---->\mathrm{CaSO}_{3}+\mathrm{CO}_{2}+\mathrm{H}_{2} \mathrm{O}$

$\mathrm{CaCO}_{3}+\mathrm{H}_{2} \mathrm{SO}_{4}---->\mathrm{CaSO}_{4}+\mathrm{CO}_{2}+\mathrm{H}_{2} \mathrm{O}$

Oxidation

$\mathrm{CaSO}_{3}+1 / 2 \mathrm{O}_{2}---->\mathrm{CaSO}_{4}$

Crystallization

$\mathrm{CaSO}_{4}+2 \mathrm{H}_{2} \mathrm{O}---->\mathrm{CaSO}_{4} * 2 \mathrm{H}_{2} \mathrm{O}$

After separation of $\mathrm{SO} 2$ this can be used to produce $\mathrm{H}_{2} \mathrm{SO}_{4}$. The gases are cooled to lower temperature and then go through a multi-stage converter system. The conversion has two steps. The $\mathrm{SO} 2$ convert into $\mathrm{SO}_{3}$ then absorption of $\mathrm{SO}_{3}$ in $\mathrm{H}_{2} \mathrm{SO}_{4}$ to form $\mathrm{H}_{2} \mathrm{SO}_{4}$, an appropriate amount of water is added to maintain the concentration of sulfuric acid (Flytzani-Stephanopoulos, et al., 2000).

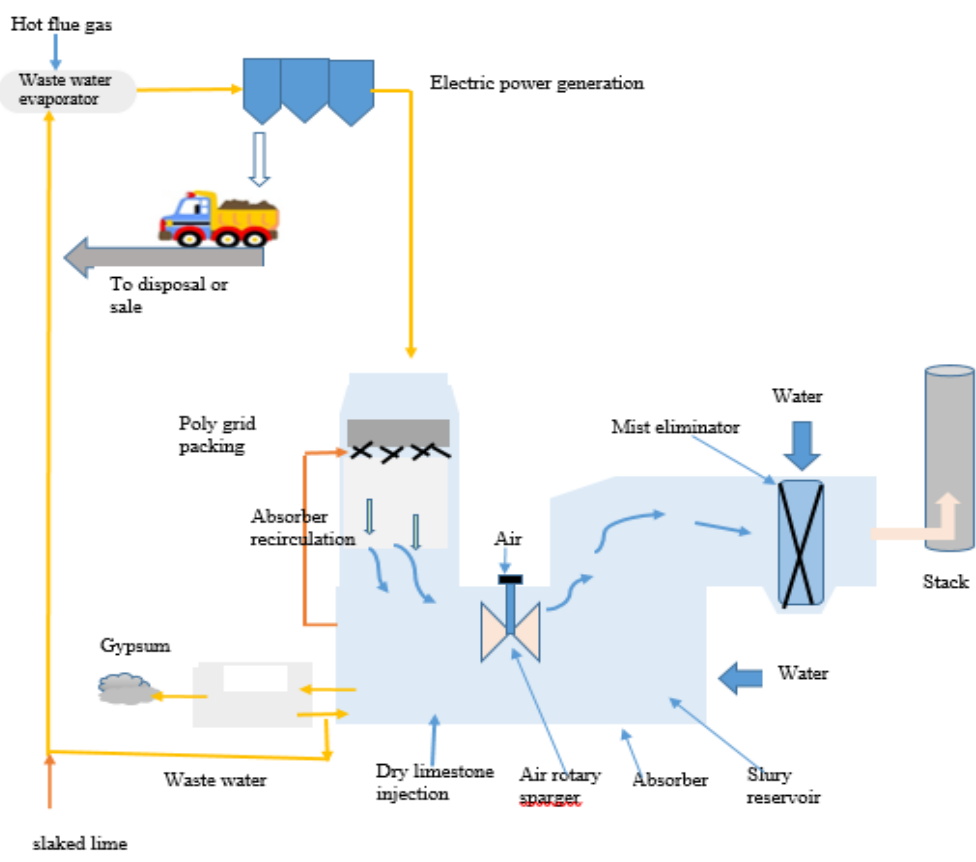

Figure 4. Demonstration of wet FGD process for power plant.

\section{Conclusion}

Though Bangladesh is a small county, it has a large population with great degree of population density and to push its economic growth various types of plans are under taken by the present government among them power generation is most important one. Government is focusing on coal-based power plant due to its higher efficiency and low production cost compare to the others. Therefore, three more plats are under construction. Yet, these power plants will help to achieve our energy demand, it will perpetuate great calamity to 
human health and environment. Therefore, mitigation process has become an essential one to overcome the future worries. The proposed process is highly efficient, but it costs us some extra charge. We need widen our view while achieving our goal. The activities of human are destroying our habitable world. Today's world is so much concern about our environment. In addition, our energy sector is one of them is responsible for world climate change. So, for the better future, it has become logical to pay some extra money while achieving our prosperity in energy sector.

\section{References}

Arslan, O., Akyürek, Ö. (2018). Spatial Modelling of Air Pollution from PM10 and SO2 concentrations during Winter Season in Marmara Region (2013-2014). International Journal of Environment and Geoinformatics, $5(1), \quad 1-16, \quad$ doi. 10.30897/ijegeo.412391.

Bayırhan, İ., Mersin, K., Tokuşlu, A., Gazioğlu, C. (2019). Modelling of Ship Originated Exhaust Gas Emissions in the Strait of Istanbul (Bosphorus). International Journal of Environment and Geoinformatics, 6(3), 238-243. doi. 10.30897/ijegeo.641397.

Craig, L., Brook, J. R., Chiotti, Q., Croes, B., Gower, S., Hedley, A., Pennell, W. (2008). Air pollution and public health: a guidance document for risk managers. Journal of Toxicology and Environmental Health, Part A, 71(9-10), 588-698.

Alam, F. (2013). Energy, Exergy and Environmental Impact Analyses of Barapukuria Coal Based Thermal Power Plant.

Prinn, R. G., Fegley Jr, B. (1987). Bolide impacts, acid rain, and biospheric traumas at the CretaceousTertiary boundary. Earth and Planetary Science Letters, 83(1-4), 1-15.

Roy, P., and Sardar, A. (2015). SO2 emission control and finding a way out to produce sulphuric acid from industrial SO2 emission. J Chem Eng Process Technol, 6, 230.

Initiative, P.P.I. (2003). Volume 1 Clean Coal Technology Programs: Program Update 2003.

Flytzani-Stephanopoulos, M., Zhu, T., Li, Y. (2000). Ceria-based catalysts for the recovery of elemental sulfur from SO2-laden gas streams. Catalysis Today, 62 (2-3), 145-158.

Dhakatribune, (2019). dhakatribune.com/ (02/08/2019).

Fioletov, V. E., McLinden, C. A., Krotkov, N., Yang, K., Loyola, D. G., Valks, P., Liu, X. (2013). Application of OMI, SCIAMACHY, and GOME-2 satellite SO2 retrievals for detection of large emission sources. Journal of Geophysical Research: Atmospheres, 118(19), 11-399.

Islam, K., Jasimuddin, M, Nath, B., Nath, T. (2016). Quantitative Assessment of Land Cover Change Using Landsat Time Series Data: Case of Chunati Wildlife Sanctuary (CWS), Bangladesh. International Journal of Environment and $\begin{array}{lll}\text { Geoinformatics, } & 3(2), & 45-55,\end{array}$ 10.30897/ijegeo.306471.
Lin, C. K., Lin, R. T., Chen, P.C., Wang, P., De Marcellis-Warin, N., Zigler, C., Christiani, D. C. (2018). A global perspective on sulfur oxide controls in coal-fired power plants and cardiovascular disease. Scientific reports, 8(1), 2611.

Mersin, K., Bayırhan, İ., Gazioğlu, C. (2019). Review of $\mathrm{CO} 2$ Emission and Reducing Methods in Maritime Transportation, Thermal Sciences, 1-8.

Rahman, M., Tamin, M., Rahman, L. (2012). Analysis of Natural Gas Consumption by the Industrial Sector of Bangladesh. Journal of Chemical Engineering, 27, 17.

Rashidin, M., Javed, S., Liu, D., Tafsirojjaman, T. (2019). An Empirical Investigation on HydroMorphological Process of Surma River: Substantiation from North-East Zone of Bangladesh, International Journal of Environment and Geoinformatics, 6(1), 83-114, doi. 10.30897/ijegeo.518468.

Safiullah, S., Khan, M. R. R., and Sabur, M. A. (2011). Comparative study of Bangladesh Barapukuria coal with those of various other countries. Journal of the Bangladesh Chemical Society, 24(2), 221-225.

Sieed, Jubair, Shaheed Hossain, and Khorshed Ahmad Kabir. (2015). Application of INPRO Methodology to Assess Economic Feasibility of Proposed Rooppur Nuclear Power Plant. International Conference on Materials, Electronics and Information Engineering, ICMEIE-2015 05-06 June, 2015, Faculty of Engineering, University of Rajshahi, Bangladesh.

Tokuşlu, A. (2020). Analyzing the Shipping Emissions in Port of Ereğli and Examining the Contribution of SOX Emissions Reduction to the Port Emissions. JENAS Journal of Environmental and Natural Studies, 2(1), 23-33.

Ülker, D., Ergüven, O., Gazioğlu, C. (2018). Socioeconomic impacts in a Changing Climate: Case Study Syria. International Journal of Environment and Geoinformatics, 5(1), 84-93, doi. 10.30897/ijegeo.406273.

Wikipedia (2020). wikipedia.org/wiki/Electricity sector in Bangladesh (20/08/2020).

www.cpgcbl.gov.bd (2019). (12.08.2019).

Zhang, L., Lee, C. S., Zhang, R., Chen, L. (2017). Spatial and temporal evaluation of long term trend (2005-2014) of OMI retrieved NO2 and SO2 concentrations in Henan Province, China. Atmospheric Environment, 154, 151-166. 